\title{
On English Enlightenment Education for 3-4-year-old Children in Multimedia Learning Environment
}

\author{
Huanhuan $\operatorname{Ren}^{1, a^{*}}$, Chi Ma ${ }^{2, b}$ \\ ${ }^{1}$ Teaching and Research Institute of Foreign Languages, Bohai University, Jinzhou 121013, China \\ 2 Jinzhou Institute of Forestry Research, Jinzhou Forestry Bureau, Jinzhou 121013, China \\ arenhuanhuan2014@163.com, ${ }^{\mathrm{b}}$ machi2014@tom.com
}

Keywords: English enlightenment education; 3-4-year-old children; Multimedia

\begin{abstract}
English enlightenment education exerts much effect on 3-4-year-old children and may be positively influential to future education of the children. It's concurred that there are many reasons for applying mobile multimedia into English enlightenment education. In this thesis, it's suggested that the implementation of English enlightenment education for 3-4-year-old children in multimedia learning environment should be carried out with three main things taken into consideration, i.e. intrinsic interest through multimedia technology, interactive activities through multimedia technology and authentic environment through multimedia technology so as to foster learners' cognitive and emotional development in language learning. It's hoped that this research may provide a useful reference for future English enlightenment education among young language students.
\end{abstract}

\section{Introduction}

With the advance in enabling technologies, multimedia have demonstrated their formidable vitality, especially in the realm of English language learning. In the meanwhile, there are many reasons for applying mobile multimedia into English enlightenment education. Based on review on trends and rationales for English enlightenment education among 3-4-year-old children and discussion on the impact of multimedia technologies on English enlightenment education, this thesis aims at finding out how to implement English enlightenment education for 3-4-year-old children in multimedia learning environment, so as to foster learners' cognitive and emotional development in English foreign language learning. This paper is a summary of this research work, which hopefully provides a useful reference for future English enlightenment education among young language students.

\section{Trends and Rationales for English Enlightenment Education For 3-4-year-old Children}

For an Early Childhood Education. In recent decades, studies have shown that early childhood education is critical in preparing children to enter and succeed in the classroom, diminishing their risk of social-emotional mental health problems and increasing their self-sufficiency as adults[1]. Parents are usually seen as a child's first teacher and therefore an integral part of the early learning process[2]. For those who want their children to potentially develop during early childhood years, they sent their children to early learning programs in hope of obtaining better and sounder childhood education. It's true that nursery specialists guide and inspire children, from baby and toddler range to action and adventure and much, much more. In recent years, early childhood education has become a prevalent public policy issue in Unites States, as lawmakers consider funding for preschool and pre-K[3]. In China, parents who have realized the years before a child reaches kindergarten among the most critical in his or her life to influence learning, start to go for an early childhood education both at home and at Early Learning Centers (or say, Children's Fitness). It's suggested that the children who have loads of fun as they develop physically, cognitively, and emotionally in early childhood processes have positive performance and attainment in future education. 
Rationale for Early English Education. Together with healthy minds and strong bodies under the guidance in a safe, clean and noncompetitive environment, English enlightenment education is pursued by parents of 3-4-year-old children. There are a lot of truth in the fact that English is the global language and the most frequently used language in the world. Knowing English opens up the world to learners in nearly any field and enables people to understand and be understood almost everywhere in the world. In China, English learning as foreign language learning is one important part of early childhood education. The truth is that, beside a sizable amount of music, play and art classes in English at home or in early learning programs, English authentic picture books and animated cartoons are also sought by both parents at home and instructors in training centers. Learning English at a young age can be provided with rationales in a plethora of literature in support of its use. It's believed that the ability to acquire language is biologically linked to age[4]. It's also claimed that there is an ideal time window to acquire language in a linguistically rich environment, after which further language acquisition becomes much more difficult and effortful[5]. With proper guidance and exploration children benefit from English enlightenment in early childhood education and begin to become more comfortable with English environment in future.

\section{The Impact of Multimedia Technologies on English Enlightenment Education For 3-4-year-old Children}

Multimedia Technologies and EFL Learning. With the rapid advance in technologies, multimedia has found their way in people's life, especially in the educational field. Language learning is closely related to media, and it's especially true for English learning as foreign language. As it's known that EFL learners can't access to the authentic learning environment as the native speaks do, and meanwhile context is one important part for language learning. Moving toward multimedia-based learning, EFL learners can enjoy a more interactive, flexible, and personalized learning opportunities. In the process, teachers should provide or even become high quality medias for learners and deliver supportive and serving actions for students' learning[6]. The traditional blackboard approach is gradually giving way to this. It has been found that mobile multimedia have demonstrated their formidable vitality, especially in the realm of English language learning, although mobile multimedia enjoy only a short history of no more than two decades, and once arouse a bitter controversy among the educators and language teachers[7]. From above, it could be concluded that multimedia-aided approach has shown their tremendous superiority over traditional one-way communication in English language.

Multimedia Technologies for English Enlightenment Education. Compared with EFL learning, multimedia aids are more required by 3-4-year-old children in English enlightenment education. Those learners are either keen with new things in language input or easily to be detracted from learning process by others. The new technologies can guarantee learners with original and authentic language input in an effective way. That is, multimedia can help students exposed to rich and contextual language with a high degree of authenticity, and establish learning platform for their interaction from learner to computer, from learner to himself, and from learner to other learning agents [8]. What's more, they modernize language learning environment with better interfaces and visual images, and make language learning materials vivid, dynamic and collaborative through non-linear structure [8]. Learners are availed of pictures, sounds, video clips etc., and it's easier for them to remember the concept or the idea delivered for longer period of time. Over time, students acquire enough language through listening so that they start to speak spontaneously. In other words, 3-4-year-old learners are provided with a supportive and engaging environment, where learners can develop oral fluency in the end with the majority of learning time spent on listening comprehension through the use of multimedia technologies. 


\section{Implementation of English Enlightenment Education for 3-4-year-old Children in Multimedia Learning Environment}

Intrinsic Interest through Multimedia Technology. In spite of the fact that English is not the most difficult languages to learn, language learning is indeed a process replete with cognitive difficulties and negative emotions. As for 3-4-year-old children, the interest in learning English should be cultivated, maintained and stimulated. With respect that traditional verbal instructions can be boring and painful for students, audio-visual tools are recommended in use, for example, nursery rhymes, animated cartoon, which are easy to come by nowadays in the Internet. Not only do audio-visual tools teach the words, they teach the right pronunciation which is not easy to forget. That is, the use of audiovisual aids convey the same meaning as words but it gives clear, easy and impressive concepts thus helping to bring effectiveness and fun in learning. It's found that the use of audio-visual provides intrinsic motivation to students by peaking their curiosity and stimulating their interests in the subjects [9]. If the fact is that learners are not convinced in five minutes that they can enjoy English, it's no use keeping them staying in the learning process any more. Thereby the teacher in kindergarten or the parent at home is encouraged to be well prepared and well organized so that the lesson flows smoothly and predictably. In this process, try to stimulate the interest of learners, especially absolute beginners of learning. It's believed that children may get excited and gain conference when they actually understand something the language guilder is saying through attentively listening and a sizable amount of language input.

Interactive Activities through Multimedia Technology. There are obvious benefits of involving 3-4-year-old children in English interactive activities. Thus how to carry out interactive activities among young learners with the help of multimedia technology? As it's found that speech develops naturally and spontaneously after learners internalize the target language through input, and that it should not be forced[10]. That is, once a foundation in listening comprehension has been established, speech evolves naturally and effortlessly out of it. In this process, learners are encouraged to speak out with their physical actions through the use of multimedia technology. According to Asher, the left hemisphere needs a great deal of experience of right-hemisphere-based input before natural speech can occur[10], and the coordination of language and action are anticipated to be build whist learners engaging in English learning. For example, imperative drills, role plays and slide presentations, among other activities, can be used to elicit physical actions and activity on the part of the learners in multimedia learning environment. Apart from providing material to listen, read and share, multimedia aids can be the basis for interaction, which parents can adjust to their child's developing needs, interests and attainments. This interactive session also develops critical thinking and reasoning that are important components of the teaching-learning process [11]. It's worthy noting that a tolerance for errors in speaking should be allowed for as young learners later have the control over the correct utterance and speech in language learning.

Authentic Environment through Multimedia Technology. English enlightenment education should be directed at the authentic environment established by the teacher or the parent, which is also an essential and valuable component for language learning. The teacher has the responsibility of providing the best kind of exposure to language so that the learner can internalize the basic rules of the target language. When we are mentioning best exposure in EFL learning environment, it means the raw material or language input must be authentic, engaging and interesting. Parents who lack confidence in English find that multimedia tools are useful props. By no means, multimedia can make learning dynamic and effective, through stimulating overall sensory experiences of young learners. Moreover, an important condition for successful language learning is the absence of stress; that is, children should learn English as natural as possible. According to some research, the key to stress-free learning is to tap into the natural bio-program for language development and thus to recapture the relaxed and pleasurable experiences that accompany first language learning [12]. EFL acquisition takes place in a natural environment just like the first language acquisition does. Virtually or 
vicariously, integrating technology into the English enlightenment is proved helpful in engaging EFL students to experience things in English-speaking countries.

\section{Conclusion}

It's concurred that English enlightenment education exerts much effects on 3-4-year-old children and may be positively influential to future education of the children. It's suggested that the implementation of English enlightenment education for 3-4-year-old children in multimedia learning environment should be carried out with three things taken into considertion, i.e. intrinsic interest through multimedia technology, interactive activities through multimedia technology and authentic environment through multimedia technology. It's hoped that benefits may accrue through English enlightenment education for 3-4-year-old children in multimedia learning environment.

\section{Acknowledgements}

This work is part of the project of On Cultivating and Developing Liaoning Scientific Foreign Language Talents with View to Bourdieu' Theory, the project of On Establishing Generative Mechanism of EFL Autonomous Learning Behaviors and Strengthening Development of Learning Field in Ubiquitous Learning Space, and the project of On Constructing Mechanism and Strategies for College English Autonomous Learning Abilities via Mobile Multimedia. This research was supported by the fund of Liaoning Planning of Philosophy and Social Science (Project No. L16CYY001), the fund of Liaoning Provincial Federation Social Science Circles (Project No. 2017lslktyb-019), and the fund of the Thirteenth Five-Year Plan of Education Sciences of Liaoning Province (Project No. JG16DB013).

\section{References}

[1] Connecticut Office of Early Childhood Planning, 2013

[2] A. A. Footnote, J. Cullen, M. Fleer, M., Early childhood education, London: SAGE, 2004.

[3] Early Learning from Birth through Third Grade, National Governor's Association.

[4] E.H. Lenneberg, Biological Foundations of Language, Wiley, 1967.

[5] Critical period hypothesis. Retrieve from the information on https://en.wikipedia.org/wiki/Critical_period_hypothesis.

[6] H. H. Ren, The Teacher's Role: From "Knowledge Ontology" to "Knowledge Media", Theory and Practice of Education, (11) 2016.

[7] F. Pan, A Study of College English Teaching Model in the Setting of Multimedia and Internet Technology, Shanghai: Shanghai International Studies University, 2007.

[8] H. H. Ren, C. Ma, Strategies on Fostering English Autonomous Learning Ability under the Influence of Mobile Multimedia, in 6th International Conference on Information Engineering for Mechanics and Materials, 2016.

[9] S. K. Mishra, B, Yadav, B, Audio-Visual Aids \& The Secondary School Teaching, Global Journal of HUMAN-SOCIAL SCIENCE, (15), 2004.

[10] J. C. Richards, T. S. Rodgers, Approaches and Methods in Language Teaching (2nd ed.), Cambridge, New York: Cambridge University Press, 2001.

[11] A. DeBernardes, E. G. Olsen, Audio-visual and community materials - some recent publications., Education Leadership, 1948. 
[12] Total Physical Response, Retrieved from the information on http://www2.vobs.at/ludescher/total_physical_response.htm 